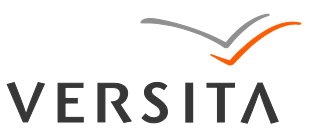

GEOCHRONOMETRIA 40(2) 2013: 145-152

DOI 10.2478/s13386-013-0104-y

Available online at

www.springerlink.com

\title{
INFLUENCE OF CLIMATE CHANGE ON CARBON AND OXYGEN ISOTOPE FRACTIONATION FACTORS BETWEEN GLUCOSE AND $\alpha$-CELLULOSE OF PINE WOOD
}

\author{
BARBARA SENSULA and ANNA PAZDUR \\ Silesian University of Technology, Institute of Physics, Department of Radioisotopes, \\ Krzywoustego 2, 44-100 Gliwice, Poland
}

Received 6 November 2012

Accepted 24 January 2013

\begin{abstract}
We present the first analysis of the influence of climate change on carbon and oxygen isotope fractionation factors for two saccharides (glucose and $\alpha$-cellulose ) of pine wood. The conifers grew in the Niepołomice Forest in Poland and the annual rings covered a time span from 1935 to $2000 \mathrm{AD}$. Glucose samples from acid hydrolysis of $\alpha$-cellulose were extracted from annual tree rings. The carbon and oxygen isotope fractionation factors between glucose and $\alpha$-cellulose were not stable over time. The mean value for the carbon isotope fractionation factors between glucose and $\alpha$-cellulose was greater than unity. The mean value for the oxygen isotope fractionation factors between glucose and $\alpha$-cellulose was lower than unity. We established, with respect to climate change, the significance of the interannual and intraannual variation in the carbon and oxygen isotope fractionation factors between both saccharides. We used moving interval correlation results for May of the previous year through September of the current year using a base length of 48 years. The relationship with summer temperature is the main climate signal in the carbon isotope fractionation factor between glucose and $\alpha$-cellulose. The relationship with autumn sunshine is the main climate signal in the oxygen isotope fractionation factor between glucose and $\alpha$-cellulose for the tree ring chronology.
\end{abstract}

Keywords: tree-rings, $\alpha$-cellulose, glucose, climate, isotope fractionation factor.

\section{INTRODUCTION}

\section{Isotope fractionation}

The consequences of the mass differences in isotopic compounds are twofold: molecules containing the heavier isotope have (i) lower mobility and (ii) generally higher binding energy (Mook, 2000; Richet et al., 1977; Żuk, 1980).

The relative deviation of the isotopic composition is expressed, in parts per thousand (\%o), as

Corresponding author: B. Sensuła e-mail: Barbara.Sensula@polsl.pl

$$
\delta=\left(\frac{\mathrm{R}_{\text {sample }}}{\mathrm{R}_{\text {standard }}}-1\right) \cdot 1000
$$

where $R_{\text {sample }}$ and $R_{\text {standard }}$ are the ratios of the heavy to the light isotope concentration in the sample and standard, respectively. The reference standard for carbon (McCaroll and Loader, 2003) is Vienna Peedee Belemnite (VPDB) and for oxygen Vienna Standard Mean Ocean Water (VSMOW).

The extent of isotopic fractionation between compounds (phases) A and B in an exchange reaction can be expressed as a fractionation factor (O'Leary, 1981) as: 
$\alpha_{\mathrm{A}-\mathrm{B}}=\frac{\mathrm{R}_{\mathrm{A}}}{\mathrm{R}_{\mathrm{B}}}=\frac{1000+\delta_{\mathrm{A}}}{1000+\delta_{\mathrm{B}}}$

Several studies (Mook, 2000; Richet et al., 1977; Żuk, 1980) have explored the temperature coefficient of fractionation in order to reproduce the reaction temperature. The isotope fractionation factor can be expressed as in the simplest case a function of temperature as follows:

$\alpha=\mathrm{C}_{1} \mathrm{e}^{\mathrm{C}_{2} / \mathrm{T}}$

The dependence of $\alpha$ on temperature is applied as a series approximation of the form:

$\ln \alpha=\mathrm{C}_{1}+\frac{\mathrm{C}_{2}}{\mathrm{~T}}+\frac{\mathrm{C}_{3}}{\mathrm{~T}^{2}}$

Expression $\mathrm{C}_{2} / \mathrm{T}$ is related to the harmonic vibrations of molecules and their rotational motion. The $\mathrm{C}_{3} / \mathrm{T}^{2}$ expression is associated with a shift in the zero point oscillations. $\mathrm{C}_{1}, \mathrm{C}_{2}$ and $\mathrm{C}_{3}$ are constants, which allow make an appropriate choice of the coefficient $\alpha$ for the reaction as a function of temperature. According to quantum theory (e.g. Mook, 2000), with increasing temperature $\ln \alpha \rightarrow 0$, so $\alpha \rightarrow 1$, as is the case of the classical theory.

\section{Isotope fractionation in tree rings}

The stable isotope ratios of light elements (carbon, oxygen and hydrogen) in plants are valuable tools in the investigation of past climate change, because of the isotopic fractionation which occurs during basic physiological processes responsible for plant growth.

Isotopic measurements of organic compounds are increasingly important in palaeoclimate reconstruction. A number of external factors determine the isotope ratios in plant tissue: (i) hydrogen and oxygen isotope compositions in rainwater become lighter with increasing latitude and altitude, (ii) environmental factors like temperature, amount of precipitation and relative humidity affect the isotope ratios in precipitation and (iii) after precipitation, isotope values can become enriched through evaporation, driven by temperature, humidity, cloudiness and wind strength.

The isotope composition of carbon and oxygen in plants tissue depends on the biosynthetic pathways within plants. Through photosynthesis, plants convert $\mathrm{CO}_{2}$ and $\mathrm{H}_{2} \mathrm{O}$ to glucose, using sunlight, and release oxygen to the atmosphere. The main carbon source of plants is atmospheric $\mathrm{CO}_{2}$. The oxygen in glucose originates from atmospheric $\mathrm{CO}_{2}$, not from $\mathrm{H}_{2} \mathrm{O}$, which is the source of the released oxygen in photosynthesis. Nevertheless, plants reflect the $\delta^{18} \mathrm{O}$ value of precipitation due to fast isotope exchange between $\mathrm{CO}_{2}$ and $\mathrm{H}_{2} \mathrm{O}$. Subsequent fractionation occurs as the lighter isotopes diffuse more easily into the chloroplast, whereas RuBisCO (ribulose-1,5bisphosphate carboxylase oxygenase; the photosynthesizing enzyme) discriminates against ${ }^{13} \mathrm{CO}_{2}$ and $\mathrm{C}^{18} \mathrm{O}^{16} \mathrm{O}$. Sugars, proteins, lipids, DNA/RNA, etc. therefore have their own specific stable isotope composition and variation in stable isotope ratios of bulk plant samples is influenced by the specific isotope ratio values for sugars, proteins and lipids. Since the ratio depends on the level of degradation, which is a function of environmental parameters, and also differs among species, compound-specific isotope measurements are now preferred in palaeoclimate investigations (O'Leary, 1981; Brader et al., 2010).

Since the beginning of the $20^{\text {th }}$ century there has been much discussion about how the external environmental factors affect the physiological processes that control tree growth. It has been reported that such effects are manifest in the width of tree rings, the wood density, the number and size of cells and the stable isotope composition of wood and its components (Schweingruber, 1996; Jacoby and D'Arrigo, 1997; Pazdur et al., 2007).

The isotope composition of carbon is attributed to discrimination in the reactions responsible for $\mathrm{CO}_{2}$ fixation (during stomatal conductance of $\mathrm{CO}_{2}$ into the leaves and during subsequent photosynthetic assimilation). Values of $\delta^{13} \mathrm{C}$ are controlled by summer sunshine and temperature, reflecting the influence of photon flux on photosynthetic rate and moisture stress (Fritz and Fontes, 1986). The isotope composition of oxygen is attributed to discrimination in the reaction responsible for water transport, and is also controlled by climate factors, which have an influence on the photosynthesis processes. Therefore the resulting $\delta^{18} \mathrm{O}$ of saccharides reflects not only the isotopic signature of the source water, but the isotopic signature of the leaf water (shifted due to water evaporation), the biochemical fractionation during biosynthesis of photosynthetic sugars and the re-equilibrium exchange between the carbohydrate and the xylem water during tree ring xylem cellulose synthesis (Roden and Ehleringer, 1999; Roden, 2008; Sternberg et al., 2003; Yakir et al., 1990).

Early studies of the stable isotope ratios in tree rings used whole wood to reconstruct climate change and to analyse the impact of human activity on the environment. Since the 1970s most palaeoclimate studies have concentrated on the analysis of $\alpha$-cellulose, as the dominant and the most easily isolated component of wood (Leavitt and Long, 1982; Libby and Pandolfi, 1974; Ehleringer and Vogel, 1993; Sjostrom, 1993). $\alpha$-cellulose $\left[\mathrm{C}_{6} \mathrm{H}_{10} \mathrm{O}_{5}\right]_{\mathrm{n}}$ is a high molecular weight $\left(>1.5 \cdot 10^{6}\right)$ linear polymer built from $\beta-1,4$ linked glucose units (Gardner and Blackwell, 1974). Since the end of the $20^{\text {th }}$ century there has been more discussion about how external environmental factors affect cell wall components such as monosaccharides and proteins. Experiments have shown that the stable isotopes of $\alpha$-cellulose provide a more reliable proxy of past climate and that whole wood does not reflect the climate in the same way as $\alpha$-cellulose (Cullen and Grierson, 2006). The immediate background to these analyses was dendrochronological research involving isotope ratio measurements on trees from Niepołomice Forest (Szczepanek et al., 2006) as part of the ISONET project 
(400 years of Annual Reconstructions of European Climate Variability using a High Resolution Isotopic Network), whereby mass spectrometric and gas chromatographic analysis of $\alpha$-cellulose samples and their hydrolysates have been extensively examined since 2004 (Sensuła et al., 2011a). Glucose concentration in the annual tree rings varied from 17 to $44 \%$.

\section{MATERIAL AND METHODS}

Niepołomice Forest is located in southern Poland $\left(49^{\circ} 59^{\prime}-50^{\circ} 07^{\prime} \mathrm{N} ; 20^{\circ} 13^{\prime}-20^{\circ} 28^{\prime} \mathrm{E}\right.$ ). Scots pine (Pinus Sylvestris L.), accompanied by oak (Quercus ruber L. and Quercus petraea L.) and black alder (Alnus glutinous L.) dominate. The period from 1935 to $2000 \mathrm{AD}$ is described in regional climate records (meteorological station near Niepołomice Forest at $50^{\circ} 07^{\prime} \mathrm{N}, 19^{\circ} 58^{\prime} \mathrm{E}$ ) by annual mean temperature ca. $8.6^{\circ} \mathrm{C}$ and annual precipitation ca. $700 \mathrm{~mm}$ (Figs. 1 and 2). The vegetative period lasts for about 218 days, beginning in April and ending in September (Szarek-Łukaszewska et al., 2002). Changes in sunshine intensity occurred in the 1980 s, decreasing before then and increasing since.

A preliminary analysis shows that the amount of glucose is a biomarker for changes in the ecosystem in which the tree grew. Differences in the structure of the $\alpha$ cellulose extracted from pine from the forest may be due to the effect of climate change and anthropogenic development by way of a metallurgical industry (Sędzimir steelworks in Cracow in 1954). External environmental factors affect the creation of the polymer and their effects
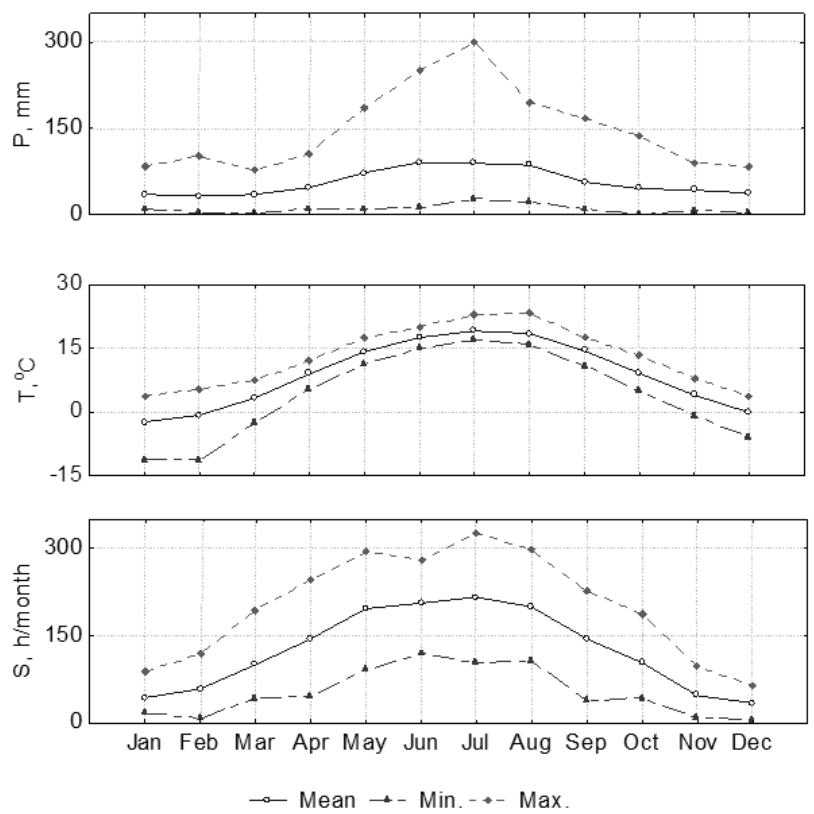

Fig. 1. Climate conditions in Niepołomice Forest (1935-2000AD): minimum, maximum and mean value of monthly sum of precipitation, monthly mean temperature and monthly hours of sunshine. are manifest in the wood and the polymer degradation during extraction of $\alpha$-cellulose. The main aim of the work here was to study the influence of climate change on carbon and oxygen isotope fractionation factors between $\alpha$-cellulose and glucose in pine wood. An analysis of the influence of amount of glucose and mannose in samples on isotope fractionation factor between glucose and $\alpha$-cellulose has been discussed; this shows that with increasing concentration of saccharides (glucose and mannose) in the $\alpha$-cellulose extracted from wood, the value of $\alpha_{c}$ increases and that of $\alpha_{o}$ decreases (Sensuła $e t$ al., 2011b).

We studied 64 samples of $\alpha$-cellulose extracted from annual pine tree rings covering 1935 to 2000 AD. Samples from $1947 \mathrm{AD}$ and $1991 \mathrm{AD}$ were excluded because there was not enough material to carry out the experiments. The $\alpha$-cellulose was extracted from consecutive tree rings, applying procedures based on Green's (1963) method, using the Mass Spectrometry Laboratory of the Silesian University of Technology. The method includes the following steps: removal of lignin, processing of holocellulose to $\alpha$-cellulose, bleaching, neutralising and drying. Hydrolysis of $\alpha$-cellulose with $72 \% \mathrm{H}_{2} \mathrm{SO}_{4}$ was performed under conditions described by Chambat et al. (1997) and based on the protocol of Saeman et al. (1954). Quantitative and qualitative analyses of the hydrolysates was carried out at CERMAV-CNRS (Grenoble, France) using a Hewlett Packard 5890 gas chromatograph equipped with a SP2380 column, and a Hewlett Packard (Agileness, Santa Clara, CA, USA) HP3395 integrator under conditions described in detail by Sensuła et al. (2011b). To displace moisture-containing air in the $\alpha$-cellulose and glucose samples, the samples were heated
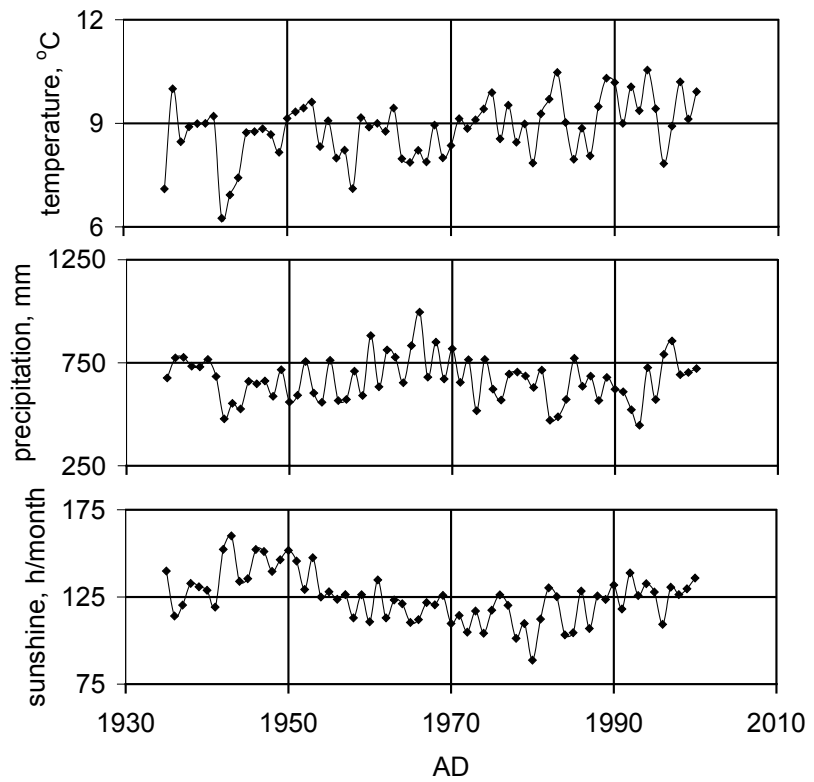

Fig. 2. Climate conditions in Niepołomice Forest (1935-2000AD): total annual precipitation, annual mean temperature and hours of sunshine. 
(24 h) under vacuum $\left(60^{\circ} \mathrm{C}\right)$ and stored in an in-house built Ar filled dry box before stable isotope ratio determination. Glucose samples were extracted and prepared as described in detail by Sensuła et al. (2011b). Measurement of carbon and oxygen isotope ratios were carried out at the Mass Spectrometry Laboratory (Department of Radioisotopes, Institute of Physics, Gliwice, Poland), using the isotope ratio mass spectrometer IsoPrime coupled to the Eurovector GV Instruments (Manchester, UK) elemental analyzer at a combustion temperature of $1020^{\circ} \mathrm{C}$ (for carbon) and at higher temperature $\left(1350^{\circ} \mathrm{C}\right)$ in a pyrolysis reactor (for oxygen). The results were standardized according to the procedure described by Treydte et al. (2007). The stable carbon and oxygen isotope analysis of $\alpha$-cellulose and glucose samples has been discussed in detail by Sensuła et al. (2011b).

DENDROCLIM2002 (Biondi, 1997; Biondi and Waikul, 2004) facilitates identification of climatic signals and potential changes over time recorded in annual tree rings. Numerical calibration of proxy climate records with instrumental observations is an essential requirement of palaeoscience. As explained by Biondi (1997), the most common statistical models used by dendrochronologists are 'correlation functions' and 'response functions'. The term 'function' stands for a sequence of computed correlation coefficients between the tree ring chronology or stable isotope composition of annual tree rings and the monthly climatic variables, which are ordered in time from the previous year's growing season to the current year's. Tree ring chronology and isotope composition of tree rings are usually regressed against monthly climate variables, especially temperature, precipitation, humidity and sunshine. In 'correlation functions' the coefficients are univariate estimates of Pearson's product moment correlation, while in 'response functions' the coefficients are multivariate estimates from principal components of the regression model. Interpretation of correlation and response functions is favoured by an accurate assessment of statistical significance, so that appropriate ecophysiological hypotheses and palaeoclimatic reconstruction can be generated. In response functions, normal significance levels of coefficients are misleading because error estimates are underestimated, so some coefficients can erroneously pass the significance test. Correlation functions can also be incorrectly tested for significance, so it is also desirable to compute bootstrapped confidence intervals for correlation functions. Analysis of temporal stability requires a large enough number of intervals and degrees of freedom within each interval. The temporal stability of climate proxy connections is an important issue in any type of palaeoclimatic reconstruction.

\section{RESULTS}

The annual rings covered the period 1935 to 2000 AD. The carbon and oxygen isotope fractionation factors between glucose and $\alpha$-cellulose calculated according to formula (2) were not stable over time (Fig. 3). The carbon isotope fractionation factor between glucose and $\alpha$-cellulose varied from 0.999 to 1.004 , whereas the oxygen isotope fractionation factor varied from 0.995 to 1.000. The mean of the carbon isotope fractionation factor between both saccharides had values greater than 1 , whereas the mean of the oxygen isotope fractionation factor is smaller than 1 .

Regarding carbon isotopic composition of saccharides, we noted that there are several period of time (e.g. early 1960 s or late 1960 's, that glucose is isotopically heavier than $\alpha$-cellulose (ca. 3\%). We estimated that the carbon isotope fractionation factor between glucose and $\alpha$-cellulose during vegetation period is $1.0030 \pm 0.0003$. Whereas oxygen isotopic composition of saccharides, showed that $\alpha$-cellulose is isotopically heavier than glucose (ca. 3\%). We estimated that the carbon isotope fractionation factor between glucose and $\alpha$-cellulose during vegetation period is $0.9970 \pm 0.0005$.

As stated above, in physical phenomena leading to isotope fractionation in chemical reactions, the fractionation factor depends primarily on temperature. Knowing that the isotopic fractionation factor between glucose and $\alpha$-cellulose can be expressed as a function of temperature (see Eq. 1.3 and Eq. 1.4) correlation coefficients were determined for fractionation of carbon and oxygen with temperature. These relationships are shown in Fig. 4, where the independent variable is the reciprocal of temperature expressed in Kelvin. On the basis of the experimental data the values of the parameters from the equations are shown in Table 1.

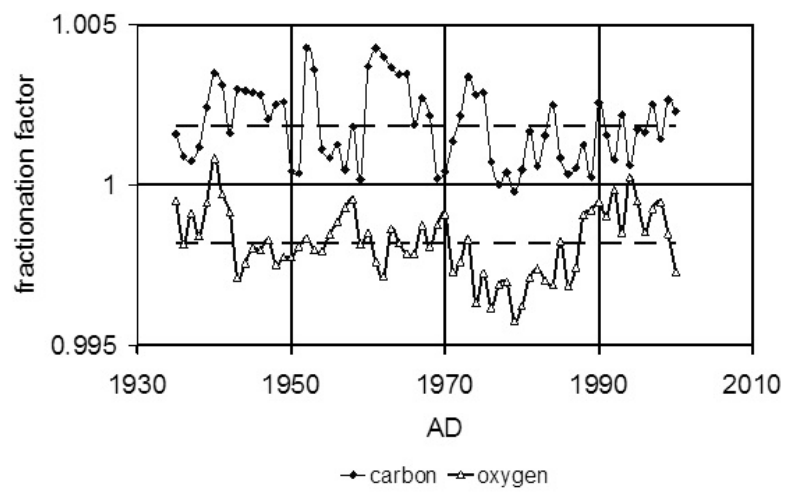

Fig. 3. Interannual variations of carbon and oxygen isotope fractionation factors (dashed line - mean values). 

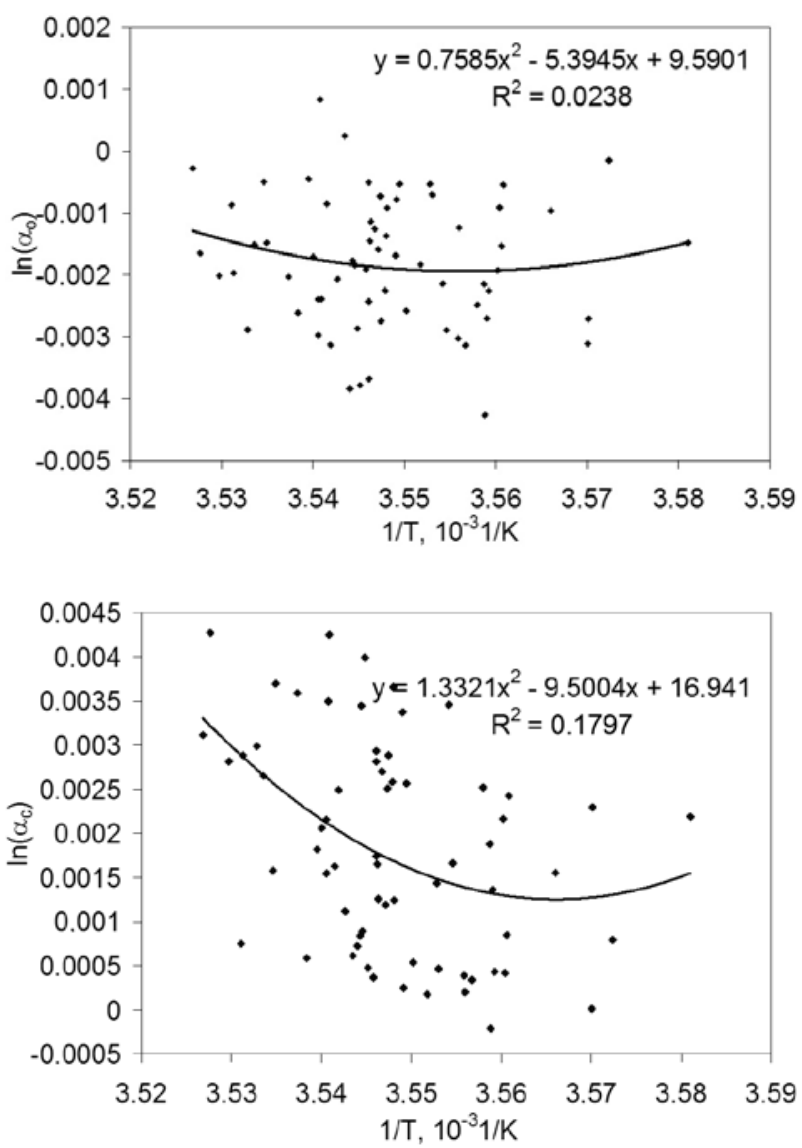

Fig. 4. Polynomial approximation according to isotopic fractionation factors from the inverse of the average annual air temperature.

\section{DISCUSSION}

\section{Isotopic fractionation factor between glucose and $\alpha$ - cellulose as a function of temperature}

The obtained relationship between isotopic fractionation factor between glucose and $\alpha$-cellulose and temperature is shown in Fig. 4. On the basis of the experimental data the values of the parameters from the equations was determined (Table 1). The data are consistent with the theory presented by Mook (2000) whereby if the temperature rises to infinity, then $\ln \alpha \rightarrow 0$, so $\alpha \rightarrow 1$.

Inasmuch as the range of temperature variations was very narrow, below $4 \mathrm{~K}$, hence the observed dependence of fractionation factor on temperature cannot be extrapolated to higher temperatures. We could not find any literature data related to it, such as the impact of temperature on the fractionation during the formation of polymer chains with cyclic compounds, in particular the creation of $\alpha$-cellulose from glucose. The model presented by Mook (2000) applies to simple chemical reactions involving simple compounds. A complicated course of reactions during photosynthesis and the creation of the polymer
Table 1. Values of $C_{1}, C_{2}$ and $C_{3}$ parameters (from Eq. 1.4) for the carbon and oxygen isotope fractionation factors.

\begin{tabular}{lllc}
\hline $\begin{array}{l}\text { Fractionation } \\
\text { factor }\end{array}$ & $\mathbf{C}_{1}$ & $\mathbf{C}_{2}$ & $\mathbf{C}_{3}$ \\
\hline $\mathrm{a}_{\mathrm{c}}$ & $1 \cdot 10^{6}$ & -9500 & 16.941 \\
\hline $\mathrm{a}_{0}$ & $0.7 \cdot 10^{6}$ & -5394 & 9.5901 \\
\hline
\end{tabular}

chain (cellulose fraction) from glucose probably can have an influence on the fractionation factors, which cannot be described by a simple exponential function, as it is in the model.

It can be assumed that the small range of average annual air temperature cannot result in a significant effect of temperature on fractionation factors between glucose and $\alpha$-cellulose. We cannot exclude the possibility that other environmental factors affect the magnitude of isotopic fractionation.

Moving interval correlation results are shown in Figs. 5 and 6, for May of the previous year through September of the current year using a base length (minimum number of years) of 48 years. The total number of predictors was 51 variables: 17 for temperature, 17 for precipitation and 17 for sunshine.

\section{Carbon isotope fractionation factor between glucose and $\alpha$-cellulose}

Moving interval correlation results (Fig. 7) show the climate factors signal recorded in the variation in carbon isotope fractionation factor between glucose and $\alpha$-cellulose, their temporal stability and the significance level. The positive relationship with August (of the current year) temperature is the main climate signal in the carbon isotope fractionation factor between saccharides for that tree ring chronology. Backward and forward evolutionary interval analysis also point to growing season sunshine as the dominant relationship, with a tendency to become more significant in recent decades.

The positive relationship with March (of the current year) temperature is the second important climate signal recorded in the carbon isotope fractionation factor between glucose and $\alpha$-cellulose for that tree ring chronology, although it is not particularly stable over time.

The third most important climate signal recorded in the carbon fractionation factor between saccharides is sum of precipitation in December (of the previous-year). This relationship has a tendency to become less significant in recent decades.

The positive relationship with July (of the previous year) precipitation and negative relationship with September (of the previous year) precipitation and July (of the previous year) sunshine was significant till the 1980s, although not particularly stable over time.

The positive relationship, with a tendency to become more significant in recent decades, was also found for the February-April (of the current-year) temperature. The 


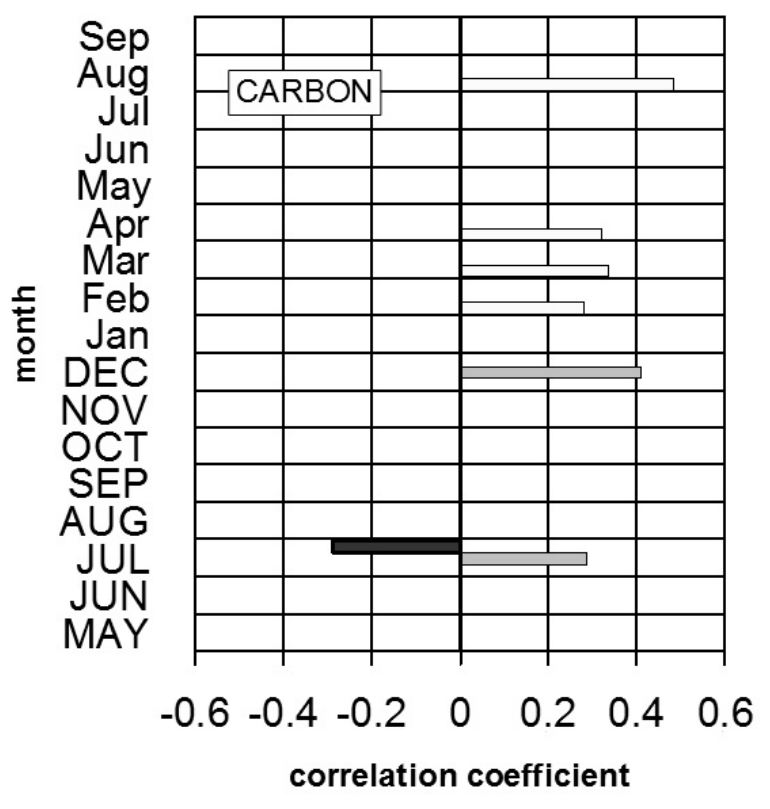

$\square$ TEMPERATURE $\square$ PRECIPITATION $\square$ SUNSHINE

Fig. 5. Correlation coefficients between the monthly mean precipitation and the carbon isotope fractionation factor for the time period 1935$2000 A D$ from previous year May to current year September (Significance level is equal 95\%).

time from February to April is the period prior to the vegetation period in Niepolomice Forest.

\section{Oxygen isotope fractionation factor between glucose and $\alpha$-cellulose}

Moving interval correlation of the climate signal recorded in variation in oxygen isotope fractionation factors between glucose and $\alpha$-cellulose (Fig. 8) shows their stability in time and the significance level. The main climate signal recorded by the oxygen isotope fractionation factor between both saccharides till the 1980s was a period of sunshine during June of the previous and current-year (positive correlation). Backward and forward evolutionary interval analysis also indicates that the sunshine during the growing season has a significant relationship with the oxygen isotope fractionation factor between glucose and $\alpha$-cellulose, and has become even less significant in recent decades. We also noted a significant correlation with participation in November of the previous year. Since the 1990s, the negative relationship with September (both of the previous and current year) sunshine has had a tendency to become more significant in recent decades. Also the positive relationship with April and September (of the current year) has become more significant. Although the temperature in March (of the current year) was not particularly stable over time, we noted a tendency for it to become more significant in

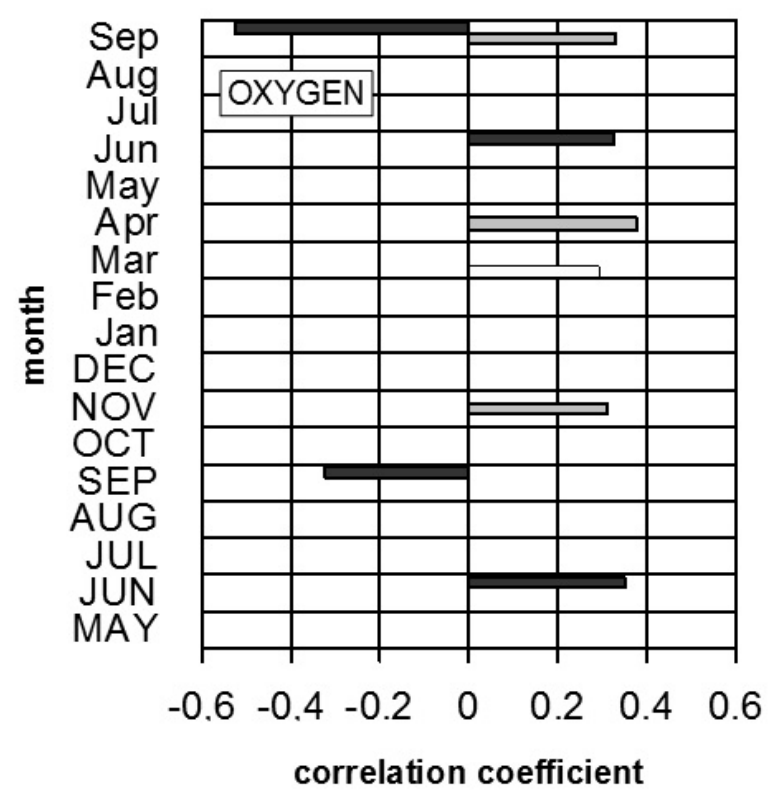

$\square$ TEMPERATURE IPRECIPITATION םSUNSHINE

Fig. 6. Correlation coefficients between the monthly mean precipitation and the oxygen isotope fractionation factor for the time period 1935$2000 A D$ from previous year May to current year September (Significance level is equal $95 \%$ ).

recent decades. The backward and forward evolutionary interval analysis also indicates that the temperature before the growing season has a significant relationship to oxygen isotope fractionation factors between glucose and $\alpha$ cellulose, and has become even more significant in recent decades.

\section{CONCLUSIONS}

External environmental factors affect the physiological processes that control tree growth. Carbon and oxygen isotope fractionation factor between glucose and $\alpha$ cellulose analysis was performed in order to understand the temporal effect of climate change on glucose and on the $\alpha$-cellulose polymer. The isotopic composition of saccharides is determined by a complex effect of climate factors. The carbon and oxygen isotope fractionation factors between glucose and $\alpha$-cellulose are not stable over time. By using statistical methods we found the climate factors which have the most significant influence on the glucose and hence on $\alpha$-cellulose formation, and in turn on the formation of the annual tree ring. The positive relationship with August (of the current year) temperature is the main climate signal in the carbon isotope fractionation factor between glucose and $\alpha$-cellulose for that tree ring chronology. Till the 1980s, the positive relationship with June (both of the previous and current year) sunshine was the main climate signal recorded in the oxygen 


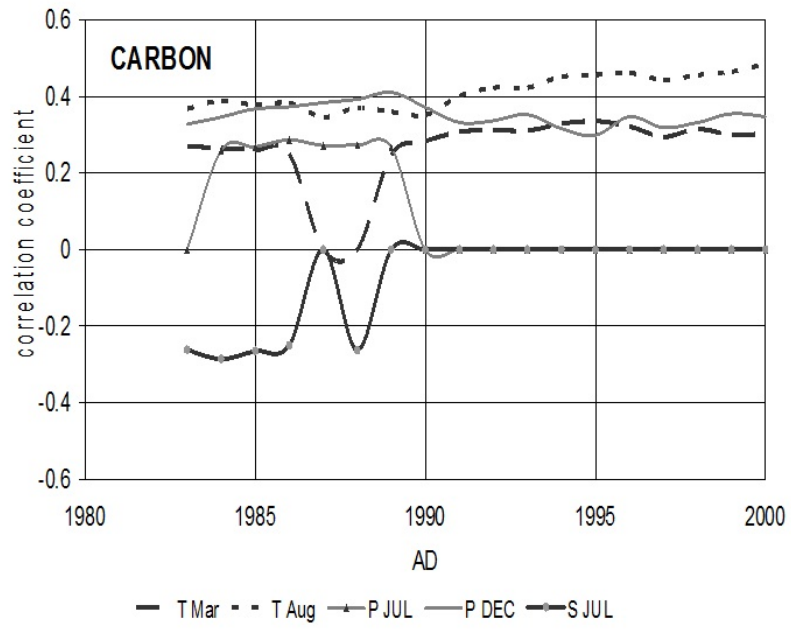

Fig. 7. Moving interval correlation results between the monthly mean precipitation and the carbon isotope fractionation factor for the time period 1935-2000AD, for May of the previous-year through September of the current-year one using a base length equal to 48. The total number of predictors is equal to 51 variables: 17 for temperature, 17 for precipitation and 17 for sunshine (Significance level is equal 95\%).

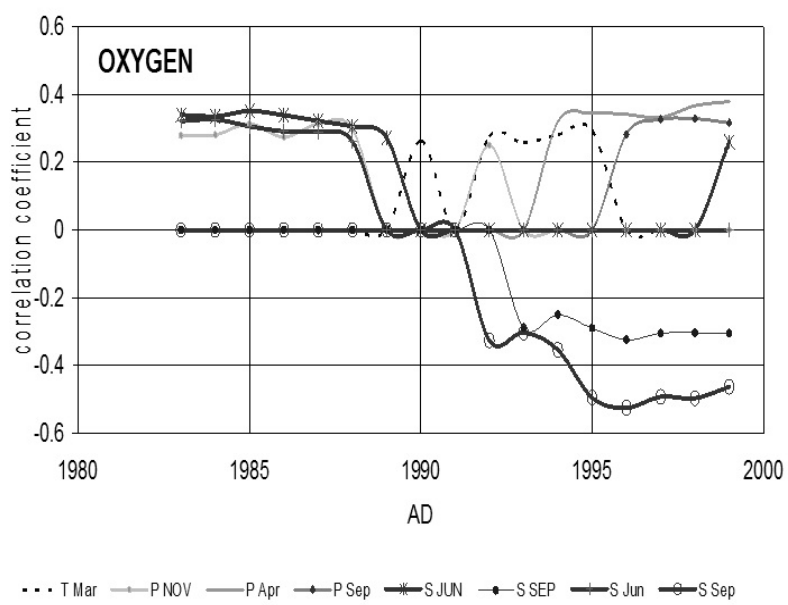

Fig. 8. Moving interval correlation results between the monthly mean precipitation and the oxygen isotope fractionation factor for the time period 1935-2000AD, for May of the previous-year through September of the current-year one using a base length equal to 48. The total number of predictors is equal to 51 variables: 17 for temperature, 17 for precipitation and 17 for sunshine (Significance level is equal 95\%).

isotope fractionation factor. Since the 1990s, the negative relationship with September (of the current-year) sunshine is the main climate signal in the oxygen isotope fractionation factor between those saccharides for that tree ring chronology. The isotopic analysis investigation will be continued in order to better decipher these complex climatic and anthropogenic effects, underlining the usefulness of such a multi-pronged analytical approach.

\section{ACKNOWLEDGEMENTS}

The authors wish to express their gratitude to everyone who contributed to making the investigation possible. In particular, we would like to express thanks to Z. Bednarz of the Agricultural University of Krakow (Cracow, Poland), E. Szychowska-Krąpiec and M. Krąpiec of the AGH University of Science and Technology (Cracow, Poland). The project was supported by the Bureau for Academic Recognition and International Exchange, Ministry of Science and Higher Education in Poland and The Embassy of France through the bourse de recherché: "Experimental and general understanding on polysaccharide synthesis in plant life cycles", Polish Ministry of Science and Higher Education N N305 016636. The dendrochronological investigations were a part of ISONET EVK2 - 2001 - 00237 project.

\section{REFERENCES}

Biondi F, 1997. Evolutionary and moving response functions in dendroclimatology. Dendrochronologia 15: 139-150.

Biondi F and Waikul K, 2004. DENDROCLIM2002: A C++ program for statistical calibration of climate signals in tree-ring chronologies. Computers \& Geosciences 30(3): 303-311, DOI 10.1016/j.cageo.2003.11.004.

Brader AV, van Winden JF, Bohncke SJ, Beets CJ, Reichart GJ and de Leeuw JW, 2010. Fractionation of hydrogen, oxygen and carbon isotopes in n-alkanes and cellulose of three Sphagnum species. Organic Geochemistry 41(12): 1277-1284, DOI 10.1016/j.orggeochem.2010.09.006.

Chambat G, Cartier N, Lefebvre A, Marais MF and Joseleau JP, 1997. Changes in cell wall and extracellular polysaccharides during the culture cycle of /Rubus fruticosus/ cells in suspension culture. Plant Physiology and Biochemistry 35: 655-664.

Cullen LE and Grierson PF, 2006. Is cellulose extraction necessary for developing stable carbon and oxygen isotope chronologies from Callitris glaucophylla? Palaeogeography Palaeoclimatology Palaeoecology 236(3-4): 206-216, DOI 10.1016/j.palaeo.2005.11.003.

Ehleringer J and Vogel J, 1993. Historical aspects of stable isotopes in plant carbon and water relations. In: Ehleringer JR, Hall JR,, Farquhar GD, eds. Stable isotopes and plant carbon/water relations. Academic Press, New York: 155-172.

Fritz P and Fontes J, 1986. Handbook of Environmental Isotope Geochemistry, Volume 1,. Elsevier eds, Amsterdam, Oxford, New York, Tokyo.

Gardner K and Blackwell J, 1974. Structure of native cellulose. Biopolymers 13(10): 1975-2001, DOI 10.1002/bip.1974.360131005.

Green JW, 1963.Wood cellulose. In: Whistler RL, eds., Methods in carbohydrate chemistry vol 3. Academic Press, New York:. 9-21.

Jacoby G and D'Arrigo R, 1997. Tree rings carbon dioxide and climatic change. Proceedings of the National Academy of Science of the USA 94: 8350-8353.

Leavitt S and Long A, 1982. Stable carbon isotopes as a potential supplemental tool in dendrochronology. Tree ring Bulletin 42: 4956.

Libby L and Pandolfi L, 1974. Temperature dependence of isotope ratios in tree rings. Proceedings of the National Academy of Science of the USA 71: 2482-2486.

McCarroll D and Loader N, 2003. Stable isotopes in tree rings. Quaternary Science Reviews 23(7-8): 771-801, DOI 10.1016/j.quascirev.2003.06.017.

Mook WG, 2000. Environmental Isotopes in the Hydrological Cycle, $1^{\text {st }}$ edition, Vol. 1: Introduction. United Nations Educational, Scientific and Cultural Organization, International Atomic Energy Agency (eds). Paris. 
O'Leary M, 1981. Carbon isotope fractionation in plants. Phytochemistry 20(4): 553-567, DOI 10.1016/0031-9422(81)85134-5.

Pazdur A, Nakamura T, Pawełczyk S, Pawlyta J, Piotrowska N, Rakowski A, Sensuła B, and Szczepanek M, 2007. Carbon isotopes in tree rings: climate and the Suess effect interferences in the last 400 years. Radiocarbon 49: 775-788.

Richet P, Bottinga Y and Javoy M, 1977. A review of hydrogen, carbon, nitrogen, oxygen, sulphur, and chlorine stable isotope fractionation among gaseous molecules. Annual Review of Earth and Planetary Science 5: 65-110, DOI 10.1146/annurev.ea.05.050177.000433.

Roden J, 2008. Cross-dating of tree ring $\delta^{18} \mathrm{O}$ and $\delta^{13} \mathrm{C}$ time series. Chemical Geology 252(1-2): 72-79, DOI 10.1016/j.chemgeo.2008.01.007.

Roden J and Ehleringer J, 1999. Observations of hydrogen and oxygen isotopes in leaf water confirm the Craig-Gordon model under wide-ranging environmental conditions. Plant Physiology 120(4): 1165-1173, DOI 10.1104/pp.120.4.1165.

Saeman J, Moore W, Mitchell R. and Millett M, 1954. Techniques for determination of pulpconstituents by quantitative Paper Chromatography. Tappi 27: 336-343.

Schweingruber F, 1996. Tree rings and environment. Dendroecology. Haupt WSL/FNP, Vienna.

Sensula B, Pazdur A, Bickerton J, and Derrick, PJ, 2011a. Probing palaeoclimatology through quantitation by mass spectrometry of the products of enzyme hydrolysis of $\alpha$-cellulose. Cellulose 18(2): 461-468, DOI 10.1007/s10570-010-9490-y.

Sensuła B, Pazdur A and Marais MF, 2011b. First application of mass spectrometry and gas chromatography in $\alpha$-cellulose hydrolysates investigation: the influence of climate changes on glucose molecules in pine tree-rings. Rapid Communications In Mass Spectrometry 25(4): 489-494, DOI 10.1002/rcm.4882.

Sjostrom E, 1993. Wood Chemistry Fundamentals and Applications. Academic Press, New York.
Sternberg L, Andreson T and Morrison K, 2003. Separating soil and leaf water ${ }^{18} \mathrm{O}$ isotopic signals in plant stem cellulose. Geochimica et Cosmochimica Acta 67(14): 2561-2566, DOI 10.1016/S00167037(03)00109-1.

Szarek-Łukaszewska G, Grodzińska K and Braniewski S, 2002. Heavy metal concentration in the moss Pleurozium schreberi in the Niepołomice Forest, Poland: changes during 20 years. Environmental Monitoring and Assessment 79(3): 231-237, DOI 10.1023/A:1020226526451.

Szczepanek M, Pazdur A., Pawelczyk S, Boettger T, Haupt M, Halas S, Bednarz Z, Krapiec M and Szychowska-Krapiec E, 2006. Hydrogen, carbon and oxygen isotopes in pine and oak tree rings from Southern Poland as climatic indicators in years 1900 - 2003. Geochronometria 25: 67-76.

Treydte KS, Frank D, Esper J, Andreu L, Bednarz Z, Berninger F, Boettger T, D'Alessandro CM, Etien N, Filot M, Grabner M, Guillemin MT, Guttierez E, Haupt M, Helle G, Hilasvuori E, Jungner H, Kalela-Brundin M, Krapiec M, Leuenberger M, Loader NJ, Masson-Delmotte V, Pazdur A, Pawelczyk S, Pierre M, Planells O, Pukiene R, Reynolds-Henne CE, Rinne KT, Saracino A, Saurer M, Sonninen E, Stievenard M, Switsur VR, Szczepanek M, Szychowska-Krapiec E and Todaro L, 2007. Signal strength and climate calibration of a European tree-ring isotope network. Geophysical Research Letters 34(24): L24302, DOI 10.1029/2007GL031106.

Yakir D, De Niro M and Ephartha J, 1990. Effects of water stress on oxygen, hydrogen and carbonisotope ratios in two species of cotton plants. Plant, Cell and Environment 13(9): 949-955, DOI 10.1111/j.1365-3040.1990.tb01985.x.

Żuk W, 1980. Procesy rozdzielania izotopów zachodzace $w$ przyrodzie (Isotope separation processes occurring in nature). In: Spektrometria mas i elektromagnetyczna separacja izotopów (Mass spectrometry and electromagnetic isotopes separation). Warszawa. PWN: 289-298 (in Polish). 